\title{
Complete Deficiency of Leukocyte Glucose-6-Phosphate Dehydrogenase with Defective Bactericidal Activity
}

\author{
M. Robert Cooper, Lawrence R. DeChatelet, Charles E. McCall, \\ Mariano F. LaVia, Charles L. SpurR, and Robert L. Baehner \\ From the Departments of Biochemistry and Medicine, Bowman Gray \\ School of Medicine, Winston-Salem, North Carolina 27103 and the \\ Division of Research Hematology, Department of Medicine, \\ Children's Hospital Medical Center, Harvard Medical School, \\ Boston, Massachusetts 02100
}

A B S TRACT A 52 yr old Caucasian female (F. E.) had hemolytic anemia, a leukemoid reaction, and fatal sepsis due to Escherichia coli. Her leukocytes ingested bacteria normally but did not kill catalase positive Staphylococcus aureus, Escherichia coli, and Serratia marcescens. An $\mathrm{H}_{2} \mathrm{O}_{2}$-producing bacterium, Streptococcus faecalis, was killed normally. Granule myeloperoxidase, acid and alkaline phosphatase, and beta glucuronidase activities were normal, and these enzymes shifted normally to the phagocyte vacuole (light and electron microscopy). Intravacuolar reduction of nitroblue tetrazolium did not occur. Moreover, only minimal quantities of $\mathrm{H}_{2} \mathrm{O}_{2}$ were generated, and the hexose monophosphate shunt (HMPS) was not stimulated during phagocytosis.

These observations suggested the diagnosis of chronic granulomatous disease. However, in contrast to control and chronic granulomatous disease leukocytes, glucose6-phosphate dehydrogenase activity was completely absent in F. E. leukocytes whereas NADH oxidase and NADPH oxidase activities were both normal. Unlike chronic granulomatous disease, methylene blue did not stimulate the hexose monophosphate shunt in F. E. cells. Thus, F. E. and chronic granulomatous disease leukocytes appear to share certain metabolic and bactericidal defects, but the metabolic basis of the abnormality differs. Chronic granulomatous disease cells lack oxidase activity which produces $\mathrm{H}_{2} \mathrm{O}_{2} ; \mathrm{F}$. E. cells had normal levels of oxidase activity but failed to produce NADPH due to complete glucose-6-phosphate dehydrogenase deficiency. These data indicate that a complete absence of leukocyte

Dr. Baehner is an established investigator of the American Heart Association and recipient of White Cell Grant No. RO1-A1-08173.

Received for publication 5 May 1971 and in revised form 20 August 1971. glucose-6-phosphate dehydrogenase with defective hexose monophosphate shunt activity is associated with low $\mathrm{H}_{2} \mathrm{O}_{2}$ production and inadequate bactericidal activity, and further suggest an important role for NADPH in the production of $\mathrm{H}_{2} \mathrm{O}_{2}$ in human granulocytes.

\section{INTRODUCTION}

Definition of the physiological and biochemical events associated with phagocytosis and intracellular killing by leukocytes has resulted in the description of several disorders of phagocyte metabolism associated with defective bacterial killing. The best known example, chronic granulomatous disease of childhood (CGD) ${ }^{1}$ was first described by Berendes, Bridges, and Good in 1957 (1). In 1966 Holmes, Quie, Windhorst, and Good (2) found that the disease was caused by inadequate killing of certain bacteria by the patient's leukocytes. Although phagocytosis was normal, ingestion of certain nonhydrogen peroxide-producing bacteria was followed by a prolonged intracellular survival of these organisms. This bactericidal defect of CGD leukocytes is characterized by deficient oxygen consumption, hexose monophosphate shunt activity $(3,4)$, nitroblue tetrazolium reduction $(4)$, and hydrogen peroxide production (5), during phagocytosis. The enzymatic basis of $\mathrm{H}_{2} \mathrm{O}_{2}$ production in phagocytising leukocytes may be due to oxidase(s) which use NADH $(6,7)$ and oxygen as substrate. Other oxidases which use NADPH (8) or amino acids (9) have also been found in PMN, but their physiologic role during phagocytosis has not been clarified. The recent studies of

\footnotetext{
${ }^{1}$ Abbreviations used in this paper: CGD, chronic granulomatous disease; G6PD, glucose-6-phosphate dehydrogenase ; HMPS, hexose monophosphate shunt; NBT, nitroblue tetrazolium; PMN, polymorphonuclear leukocytes.
} 
Klebanoff (10) have demonstrated that $\mathrm{H}_{2} \mathrm{O}_{2}$ combined with myeloperoxidase and halide ion, kills bacteria. The lack of killing in CGD cells can be improved in vitro by insertion of a $\mathrm{H}_{2} \mathrm{O}_{2}$-generating oxidase into their phagocytic vacuoles $(11,12)$.

The precise role of leukocyte hexose monophosphate shunt (HMPS) activity to $\mathrm{H}_{2} \mathrm{O}_{2}$ production and bacterial killing is uncertain. We have encountered a 52 yr old white female (F. E.) with recurrent and fatal Gram-negative infection and absent HMPS activity with low $\mathrm{H}_{2} \mathrm{O}_{2}$ production by her leukocytes during phagocytosis. This PMN lesion differed from CGD PMN's since the oxidases which produce $\mathrm{H}_{2} \mathrm{O}_{2}$ were normal (4) but reduced pyridine nucleotide generating glucose-6-phosphate dehydrogenase (G6PD) activity was completely absent, and methylene blue did not stimulate the hexose monophosphate shunt in F. E. leukocytes. The metabolic consequences of this deficiency are examined in this report.

\section{CASE REPORT}

F. E., a 52 yr old white married female was initially seen in December of 1947, at the age of 30, with a history of night sweats, a 10-15 lb. weight loss and painful splenomegaly. In February of 1948 F. E.'s spleen was palpable $21 \mathrm{~cm}$ below the left costal margin. Her hemoglobin was $7.1 \mathrm{gm} / 100 \mathrm{ml}$, white count was $75,000 / \mathrm{mm}^{3}$ with a differential of $43 \%$ polymorphonuclear leukocytes, $22 \%$ bands, $27 \%$ metamyelocytes, $4 \%$ myelocytes, $1 \%$ myeloblasts, $2 \%$ lymphocytes, $1 \%$ monocytes, and $5 \%$ nucleated red blood cells were seen per 100 white cells. The spleen was irradiated with $1500 \mathrm{R}$ and the white count decreased to $5000 / \mathrm{mm}^{8}$. The spleen was again irradiated in 1949 and 1950 because of anemia and leukocytosis, and in $1951,{ }^{22} \mathrm{P}$ was administered. Because of increasing splenomegaly and a Coombs negative hemolytic anemia with a reticulocytosis of $33 \%$, a splenectomy was performed in May 1951. The spleen weighed $1050 \mathrm{~g}$ and pathologic examination showed fibrosis and extramedullary erthropoiesis with granulocytic, megakaryocytic, and erythroid precursors present. Postsplenectomy, the white count ranged from 71,000 to $200,000 / \mathrm{mm}^{8}$. The hemoglobin was $6-8 \mathrm{~g} / 100 \mathrm{ml}$, and the patient required repeated blood transfusions. At this time, frequent upper respiratory infections occurred. A cataract was removed from the right eye in 1960 and from the left eye in 1962. In 1963, deep cellulitis developed in the left lower leg. In February 1965, a urinary tract infection occurred which was responsive to sulfonamides. On 25 May 1966, bronchopneumonia occurred in the anterior basilar segment of the right lower lobe. She developed pneumonia and septicemia due to $E$. coli in August 1969, and her illness responded to treatment with cephalothin and kanamycin. This illness recurred in September 1969, and she was treated with gentamicin and kanamycin. The patient remained afebrile and was discharged from the hospital. Kanamycin was continued at a dosage of $250 \mathrm{mg}$ intramuscularly daily thereafter. In November 1969, E. coli sepsis recurred together with Klebsiella pneumoniae sepsis and she expired in January 1970.

During the patient's terminal illness, the white count varied from 16,000 to $70,000 / \mathrm{mm}^{8}$. Repeated bone marrow aspirations and peripheral blood differentials showed no morphological change from 1949 to December 1969.
The patient's blood histamine, serum $B_{12}$ level, and unbound binding capacity for $\mathrm{B}_{12}$ were within the normal range. The creatinine clearance was $18 \mathrm{ml} / \mathrm{min}$. The Philadelphia chromosome was not found and no other chromosomal abnormalities were observed.

Red cell glucose-6-phosphate dehydrogenase, (G6PD) activity was low, and leucocyte glucose-6-phosphate dehydrogenase, (G6PD) was practically absent.

The family history was significant in that four brothers, three sisters, and the only living child ( $29 \mathrm{yr}$ old male), had normal red cell and leukocyte glucose-6-phosphate dehydrogenase levels. An increased incidence of infection or occurrence of anemia or hemolysis was not elicited in the family. The patient's father had expired and her mother would not allow blood studies to be performed.

\section{METHODS}

Leukocyte isolation. Leukocytes were isolated largely free of platelets and red cells by sedimentation and gentle centrifugation from $50 \mathrm{cc}$ of heparinized venous blood. The white cells were washed with $0.9 \%$ saline. They were then suspended in $6 \mathrm{ml}$ of cold distilled water for red cell lysis, and isotonicity was restored with $2 \mathrm{ml}$ of $3.5 \%$ salines. The resulting white cells were suspended in phosphate-buffered saline, counted in a Coulter counter (Coulter Electronics, Inc., Hialeah, Fla.), and brought to the desired concentration by adding phosphate-buffered saline to the cell suspension (13). Viability was determined by $1 \%$ Trypan Blue. Differentials were performed in the counting chamber by classifying cells as phagocytes (segmented and band-form neutrophils, eosinophils, and monocytes) and lymphocytes. The lymphocytes accounted for less than $10 \%$ of the isolated cell suspension. In addition, differentials were performed on peripheral blood prepared with Wright's stain. The degree of maturity remained constant throughout the study.

Quantitative nitroblue tetrazolium test. Quantitation of the reduction of nitroblue tetrazolium to the insoluble blue formazan was done by the method of Baehner and Nathan (14).

Metabolic studies. Leukocyte oxygen consumption was measured using the oxygen electrode polarographic method as previously described (6).

Hydrogen peroxide production was measured by determining the amount of ${ }^{14} \mathrm{CO}_{2}$ generated from $\mathrm{Na}^{14} \mathrm{COOH}$. $1 \mu \mathrm{Ci}$ of ${ }^{14} \mathrm{C} \mathrm{Na}{ }^{14} \mathrm{COOH}$ formate was added to $0.8 \mathrm{cc}$ of the leukocyte suspension containing $4 \times 10^{7}$ cells $/ \mathrm{mm}^{3}$. Then $0.1 \mathrm{cc}$ of polystyrene particles was added to the flask by a sidearm and the cells were allowed to phagocytize for $30 \mathrm{~min}$ at $37^{\circ} \mathrm{C}$ in a Dubnoff metabolic shaking incubator (Precision Scientific Co., Chicago, Ill.). ${ }^{11} \mathrm{CO}_{2}$ was trapped in a center vial with $0.1 \mathrm{cc}$ of $10 \%$ sodium hydroxide. The reaction was stopped by transferring the flask to an ice bath where it revolved for $30 \mathrm{~min}$ to permit further ${ }^{14} \mathrm{CO}_{2}$ diffusion from the incubation media. The alkali was then washed from the center well with $10 \mathrm{ml}$ of scintillation fluid and the ${ }^{14} \mathrm{CO}_{2}$ activity was counted in a Packard Tri-Carb (Packard Instrument Co., Inc., Downers Grove, Ill.) scintillation spectrometer.

Hexose monophosphate shunt activity and Krebs' cycle activity were determined by suitable modifications of the methods of Beck $(15,16)$, and Sbarra and Karnovsky (17) utilizing glucose-1- ${ }^{14} \mathrm{C}$ and glucose- $6-{ }^{14} \mathrm{C}$, respectively.

Enzyme studies. For the in vitro measurement of enzyme activities, cells were suspended in phosphate-buffered saline 
and disrupted by sonication as previously described $(13,18)$. Cellular debris was removed by centrifugation at $27,000 \mathrm{~g}$ for $15 \mathrm{~min}$ and the enzyme activities of supernates were then determined immediately. The protein concentration of sonicates was estimated by the biuret method (19).

The activities of leukocyte 6-phosphogluconic acid dehydrogenase (20) and glucose-6-phosphate dehydrogenase (21) were measured spectrophotometrically. The initial rate of formation of NADPH was determined at $340 \mathrm{~m} \mu$ in a Beckman DU spectorometer (Beckman Instruments, Inc., Fullerton, Calif.) with a Gilford recorder (Gilford Instrument Laboratories, Inc., Oberlin, Ohio). The enzyme activity in micromoles per minute was calculated using the molar extinction coefficient for NADPH of 6,200 .

Red cells were hemolyzed in 4 volumes of $0.01 \mu$ Tris buffer, $\mathrm{pH} 7.4$ at $0-4^{\circ} \mathrm{C}$. Assays for red cell enzymes were performed on $0.10-\mathrm{ml}$ portions of this hemolysate.

$\mathrm{NADH}$ and NADPH oxidase activities were determined according to the method of Cagan and Karnovsky (7) as modified by Baehner and Nathan (14).

Acid and alkaline phosphatase, beta glucuronidase, and myeloperoxidase were assayed according to the methods previously reported (22).

Phagocytic and bactericidal activities. Phagocytic and bactericidal activities were determined by a modification of the Maaløe technique (23). Stock strains of E. coli, $S$. aureus, $S$. marcescens, and $S$. faccalis were used. An $18 \mathrm{hr}$ culture in broth was centrifuged, washed once, and suspended in saline to a standardized optical density of 0.08 at $620 \mathrm{~m} \mu$ in a Coleman Junior spectrophotometer (Coleman Instruments, Maywood, Ill.). The bacterial suspension was added to a suspension of phagocytes in a ratio of approximately 10 bacteria to 1 phagocyte. A final concentration of $10 \%$ fresh serum obtained from normal volunteers was employed in each sample.

Electron microscopic studies of myeloperoxidase were performed by the method of Baehner, Karnovsky, and Karnovsky (22). Iodination was performed by the method of Klebanoff (10). Control and F. E. leukocytes were incubated with a culture of $E$. coli isolated from F. E., and Eagles-199 medium in the presence of ${ }^{125} \mathrm{I}$. Smears of these cellular suspensions were then fixed in absolute methanol and radioautographs were prepared.

\section{RESULTS}

A screening test for nitroblue tetrazolium reduction showed no evidence of NBT reduction. Subsequent studies showed that F. E. leukocytes failed to reduce nitroblue tetrazolium to the insoluble blue formazan over a $2 \mathrm{hr}$ period (Fig. 1), and nitroblue tetrazolium reduction was not observed in the phagocytic vacuoles of F. E. leukocytes. However, sonicates of F. E. leukocytes did reduce nitroblue tetrazolium normally when NADPH or NADH was added to the reaction mixture.

Hexose monophosphate shunt activity with and without phagocytosis of polystyrene particles was studied in 20 normal individuals and in four separate studies on patient F. E. ${ }^{14} \mathrm{CO}_{2}$ release from glucose- $6-{ }^{14} \mathrm{C}$ was normal in F. E. cells, but a total lack of hexose monophosphate shunt activity as measured by ${ }^{14} \mathrm{CO}_{2}$ released from glucose- $1{ }^{14} \mathrm{C}$ was observed in both resting and phagocytizing states (Table I). These findings are similar to the

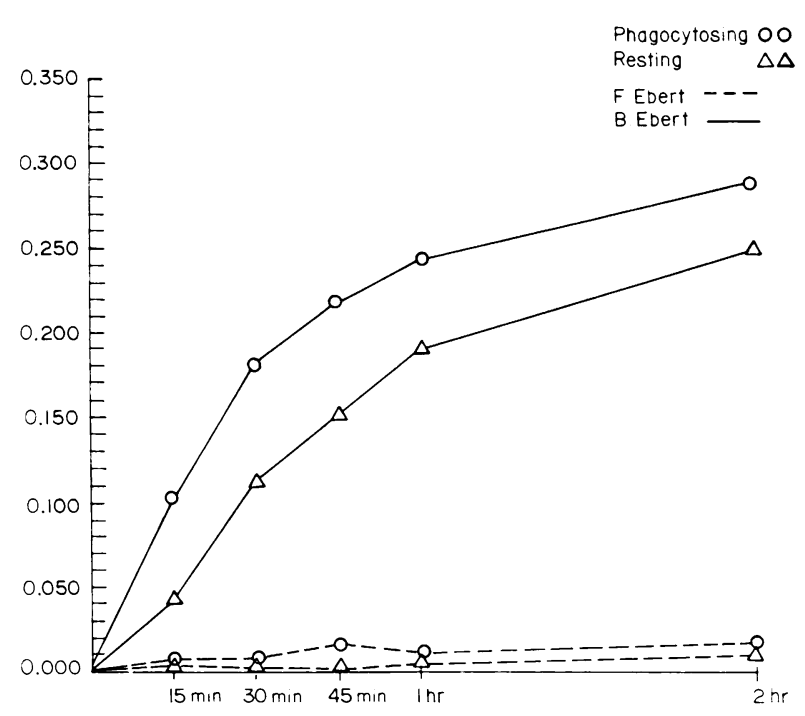

FIGLRE 1 Quantitative nitroblue tetrazolium study comparing patient $F$. E. with her only living child, B. E. (Male).

results in patients with chronic granulomatous disease $(3,4)$.

Methylene blue stimulates hexose monophosphate shunt activity of PMN's from children with chronic granulomatous disease (4). In contrast, methylene blue did not stimulate the hexose monophosphate shunt in F. E. leukocytes (Table I).

Hydrogen peroxide production was decreased compared to normals in resting and particularly in phagocytizing CGD and F. E. leukocytes (Table II). Leukocyte alkaline phosphatase was initially low both by histochemical and by quantitative techniques from 22 March 1966 to 19 September 1969, whereas other lysosomal en-

\section{TABLE I}

Krebs' Cycle and Hexose Monophosphate Shunt Activity in Phagocytes of G6PD-Deficient and CGD Patients

\begin{tabular}{|c|c|c|c|}
\hline & $\begin{array}{l}\text { Control, } \\
\mathrm{n}=20\end{array}$ & $\begin{array}{l}\text { F. E., } \\
n=4\end{array}$ & $\begin{array}{l}\mathrm{CGD} \\
\mathrm{n}=2\end{array}$ \\
\hline $\begin{array}{l}\text { Glucose-6-14C } \\
\text { (without particles) }\end{array}$ & $\begin{array}{l}\bar{X}=213^{*} \\
\text { SD } \pm 87\end{array}$ & $\bar{X}=36.3$ & $\bar{X}=418$ \\
\hline $\begin{array}{l}\text { Glucose-6-14 } \mathrm{C} \\
\text { (w1th particles) }\end{array}$ & $\begin{array}{l}\bar{X}=527 \\
S D \pm 231\end{array}$ & $\bar{X}=627$ & $\overline{\mathrm{X}}=306$ \\
\hline $\begin{array}{l}\text { Glucose-6-14C } \\
\text { ( } 2 \text { mis methylene blue) }\end{array}$ & $\begin{array}{l}\bar{X}=206 \\
S D \pm 76\end{array}$ & $\bar{X}=189$ & $\bar{X}=200$ \\
\hline $\begin{array}{l}\text { Glucose-1-14C } \\
\text { (without particles) }\end{array}$ & $\begin{array}{l}\bar{X}=724 \\
\text { SD } \pm 278\end{array}$ & $\bar{X}=391$ & $\bar{x}=550$ \\
\hline $\begin{array}{l}\text { Glucose- } 1-14 \mathrm{C} \\
\quad \text { (with particles) }\end{array}$ & $\begin{array}{l}\bar{X}=5319 \\
S D \pm 1090\end{array}$ & $\bar{X}=485$ & $\bar{x}=720$ \\
\hline $\begin{array}{l}\text { Glucose-1-14C } \\
\text { (2 mir methylene blue) }\end{array}$ & $\begin{array}{l}\bar{X}=4640 \\
S D \pm 800\end{array}$ & $\bar{X}=213$ & $\bar{X}=4882$ \\
\hline
\end{tabular}

CGD = chronic granulomatous disease. Each recorded observation on patient F. E. and CGD is the mean of at least four observations.

* Results expressed as counts per minute per $5 \times 10^{6}$ phagocytes (mature PMN, band forms, eosinophils, and monocytes). 

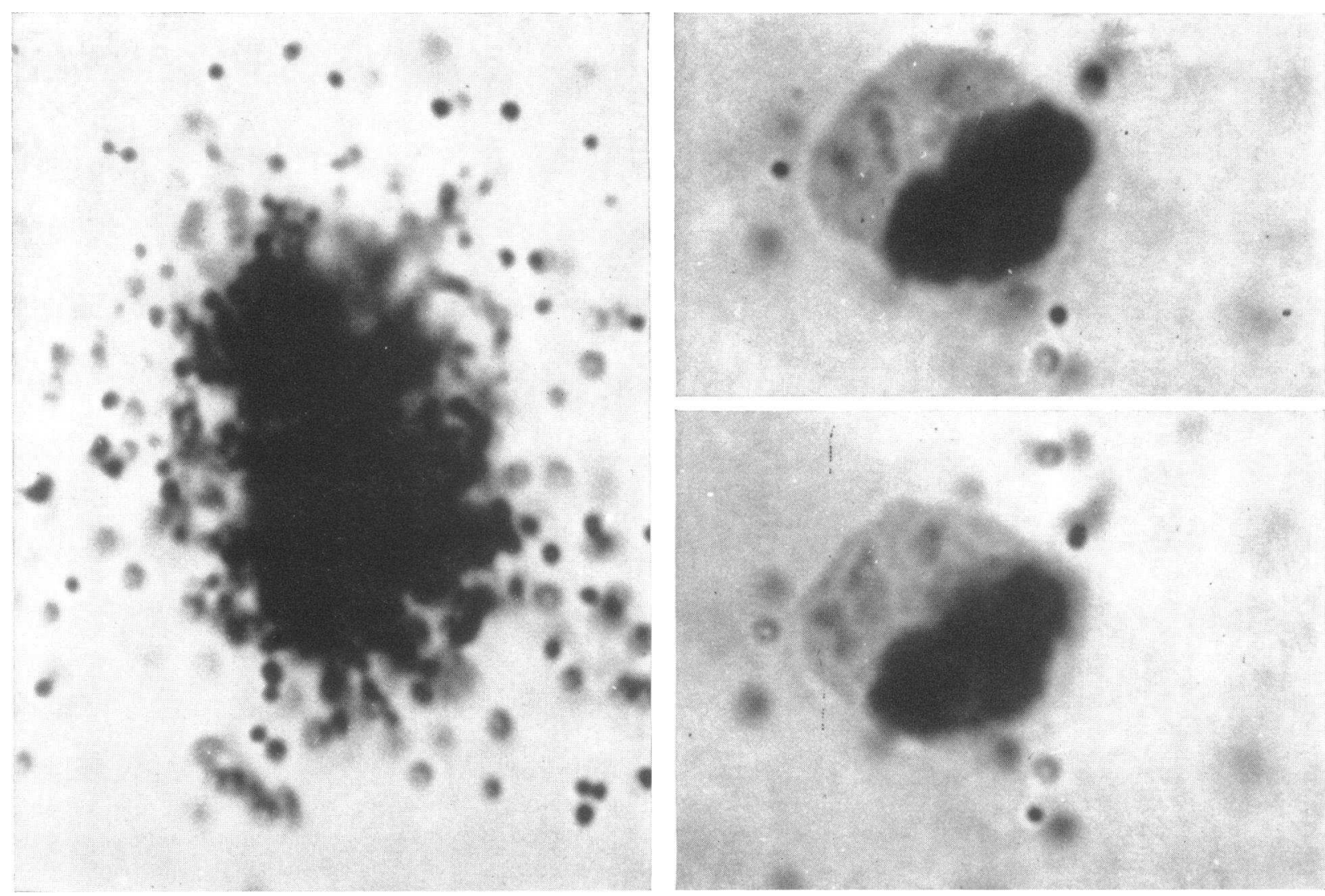

FIGURE 2 Radioautographs of control (left) and patient F. E. (right) using E. coli and ${ }^{125} \mathrm{I}$.

zymes such as acid phosphatase, beta glucuronidase, and myeloperoxidase were quantitatively normal or increased (Table III). During one episode of severe sepsis leukocyte alkaline phosphatase returned to the normal range $(0.68 \mu \mathrm{M} / \mathrm{hr}$ per mg protein).

The rate of phagocytosis of zymosan by F. E. cells was quantitatively normal after an initial delay in up-
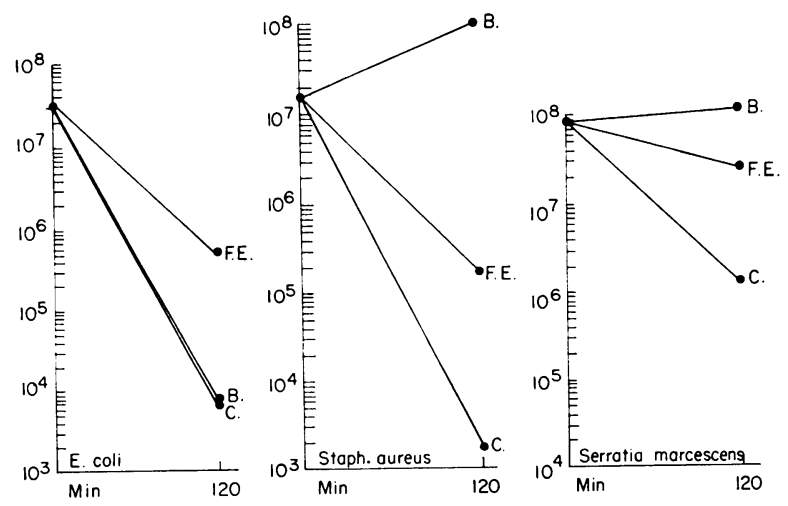

FIgURE 3 In vitro bactericidal activity of control (C) and patient (F. E.) PMNL using non- $\mathrm{H}_{2} \mathrm{O}_{2}$-producing bacteria. B., bacteria alone; C., bacteria with control leukocytes; F. E., bacteria with patient leukocytes. take (Table IV). In addition, polystyrene particles were engulfed normally by F. E. leukocytes.

Radioautographic studies with E. coli and Iodide-125 showed normal ingestion of $E$. coli but an inability of

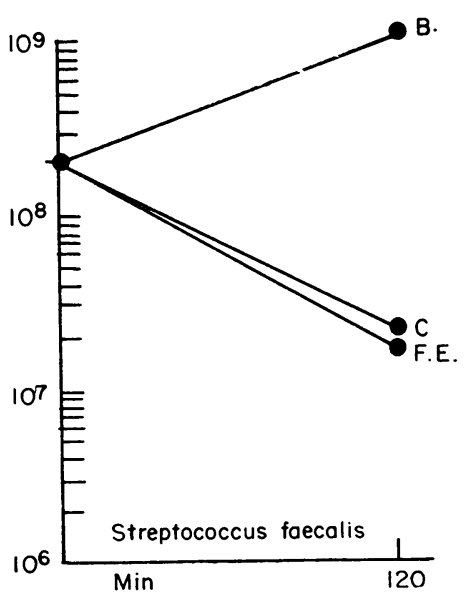

Figure 4 In vitro incubation of control and F. E. PMNL with an $\mathrm{H}_{2} \mathrm{O}_{2}$-producing bacterium. B., bacteria alone; $\mathrm{C}$., bacteria with control leukocytes; F. E., bacteria with patient leukocytes. 
TABLE II

Hydrogen Peroxide Production in Patient F. E. Compared to Controls and Chronic Granulomatous Disease

\begin{tabular}{lll}
\hline & \multicolumn{1}{c}{ Resting } & Phagocytizing \\
\hline Control $(\mathrm{n}=8)$ & $0.30,{ }^{*}$ SD \pm 0.16 & 2.7, SD 0.66 \\
CGD $\quad(\mathrm{n}=4)$ & 0.06, SD \pm 0.05 & 0.23, SD 0.13 \\
F. E. & 0.06, SD \pm 0.04 & 0.12, SD 0.06
\end{tabular}

* Results expressed as nanomoles of formate- ${ }^{14} \mathrm{C}$ oxidized to ${ }^{14} \mathrm{CO}_{2} \mathrm{mg}^{-1}$ protein $\mathrm{hr}^{-1}$.

F. E. leukocytes to iodinate bacteria as compared to controls (Fig. 2).

Bactericidal studies revealed that F. E. cells killed hydrogen peroxide-producing organisms such as $S$. fae-

\section{TABLE III}

Summary of Quantitative Values of Human WBC Enzymes of Patient F. E. Compared to Infected Controls

\begin{tabular}{lll}
\hline & $\begin{array}{c}\text { Infected } \\
\text { controls } \\
(\mathrm{n}=9)\end{array}$ & F. E. \\
\hline Acid phosphatase, & & \\
$\quad O D U / m g$ per 10 min & $4.0, \mathrm{SD} \pm 1.4$ & 4.1 \\
Alkaline phosphatase, \\
$\quad O D U / m g$ per $30_{-}^{\circ}$ min \\
$\begin{array}{c}\text { Beta glucuronidase, } \\
\text { OD } U / m g \text { per } 3 \mathrm{hr}\end{array}$ & $6.2, \mathrm{SD} \pm 3.5$ & 2.2 \\
$\begin{array}{c}\text { Peroxidase, OD } U / \mathrm{mg} \\
\text { per min }\end{array}$ & $0.86, \mathrm{SD} \pm 0.97$ & 1.58 \\
\hline
\end{tabular}

calis (Fig. 3) but could not kill E. coli, S. aureus, or $S$. marcescens, all of which are catalase positive and do not produce $\mathrm{H}_{2} \mathrm{O}_{2}$ (Fig. 4).

TABLE IV

Kinetic Study of Uptake of Zymosan Particles

\begin{tabular}{|c|c|c|c|c|}
\hline \multirow[b]{2}{*}{ Min } & \multicolumn{2}{|c|}{$\begin{array}{l}\text { Amount cells } \bar{c} \\
\text { ingested zymosan }\end{array}$} & \multicolumn{2}{|c|}{$\begin{array}{l}\text { No. of zymosan } \\
\text { ingested per cell }\end{array}$} \\
\hline & Control & F. E. & Control & F. E. \\
\hline & \multicolumn{2}{|c|}{$\%$} & & \\
\hline 0 & 0.0 & 0.0 & 0.0 & 0.0 \\
\hline 1 & 14.8 & 0.0 & 0.3 & 0.0 \\
\hline 2 & 50.4 & 0.0 & 1.0 & 0.0 \\
\hline 3 & 82.3 & 3.8 & 2.2 & 2.5 \\
\hline 4 & 86.0 & 10.0 & 2.9 & 2.5 \\
\hline 5 & 75.0 & 51.0 & 2.5 & 2.5 \\
\hline 10 & 94.0 & 74.0 & 5.2 & 2.9 \\
\hline 15 & 96.5 & 85.0 & 4.9 & 3.0 \\
\hline
\end{tabular}

Particle:cell ratio, $4: 1$ at $37^{\circ} \mathrm{C}$.
TABLE $V$

Oxidase Activity and Hexose Monophosphate Enzymes Activity

\begin{tabular}{llc}
\hline & \multicolumn{1}{c}{$\begin{array}{c}\text { Controls, } \\
(\mathrm{n}=12)\end{array}$} & $\begin{array}{c}\text { F. E., } \\
(\mathrm{n}=6)\end{array}$ \\
\hline G6PD* $^{*}$ & $0.180, \mathrm{SD} \pm 0.026$ & $0.003, \mathrm{SD} 0.001$ \\
6PGD $^{*}$ & $0.085, \mathrm{SD} \pm 0.009$ & $0.079, \mathrm{SD} 0.014$ \\
DPNH oxidase $^{+}$ & $1.64, \mathrm{SD} \pm 0.41$ & 1.01 \\
TPNH ${ }_{\ddagger}^{+}$oxidase & $1.26, \mathrm{SD} \pm 0.74$ & 0.90 \\
\hline
\end{tabular}

* Results expressed as $\mu$ mole $\mathrm{mg}^{-1} \mathrm{~min}^{-1}$.

$\ddagger$ Results expressed as $\mu \mathrm{l} \mathrm{O}_{2}$ consumed $\mathrm{mg}^{-1} \mathrm{hr}^{-1}$. Results on F. E represent mean of duplicate assays.

Electron micrographs of F. E. cells showed adequate ingestion of $E$. coli and normal degranulation of myeloperoxidase into the phagocytic vacuole (Fig. 5). In addition, alkaline phosphatase, acid phosphatase, and beta glucuronidase degranulation were quantitatively normal.

$\mathrm{NADH}$ and NADPH activities were normal (Table $\mathrm{V})$. The activities of the first two shunt enzymes, glucose-6-phosphate dehydrogenase and 6-phosphogluconic acid dehydrogenase were determined in sonicates of control and F. E. leukocytes. F. E. leukocytes completely lacked glucose-6-phosphate dehydrogenase while possessing normal 6-phosphogluconic acid dehydrogenase activity (Table V). Repetitive studies on F. E. leukocytes showed that there was practically no glucose-6phosphate dehydrogenase in her white cells. The presence of an inhibitor was ruled out by adding equal amounts of F. E. and normal sonicates and showing no inhibition of glucose-6-phosphate dehydrogenase activity.

In addition to the complete deficiency of leukocyte glucose-6-phosphate dehydrogenase, depressed activity of this enzyme was found in red cell hemolysates (Table VI). However, the red cell study was performed after the patient was transfused with $2 \mathrm{U}$ of packed red cells when the absolute reticulocyte count was $8 \%$. Thus F. E.'s mature red cell glucose-6-phosphate dehydro-

TABLE VI

Erythrocyte Glucose-6-Phosphate Dehydrogenase and 6-Phosphogluconic Acid Dehydrogenase Activity

\begin{tabular}{|c|c|c|c|}
\hline & $\begin{array}{l}\text { Normal. } \\
(\mathrm{n}=9)\end{array}$ & $\begin{array}{l}\text { Negroes with } \\
\text { G6PD deficiency, } \\
(\mathrm{n}=4)\end{array}$ & $\begin{array}{l}\text { F. E., } \\
(\mathrm{n}=1)\end{array}$ \\
\hline G6PD & $\begin{array}{l}\bar{X}=1.100^{*} \\
\mathrm{SD} \pm 0.05\end{array}$ & $\bar{X}=0.245$ & $\bar{X}=0.425$ \\
\hline 6PGD & $\begin{array}{l}\bar{X}=0.650 \\
\mathrm{SD} \pm 0.10\end{array}$ & $\bar{X}=0.700$ & $\bar{X}=0.750$ \\
\hline
\end{tabular}

${ }^{*} \mu \mathrm{M} \mathrm{TPNH} / \mathrm{min}$ per $\mathrm{ml}$ of packed erythrocytes. 


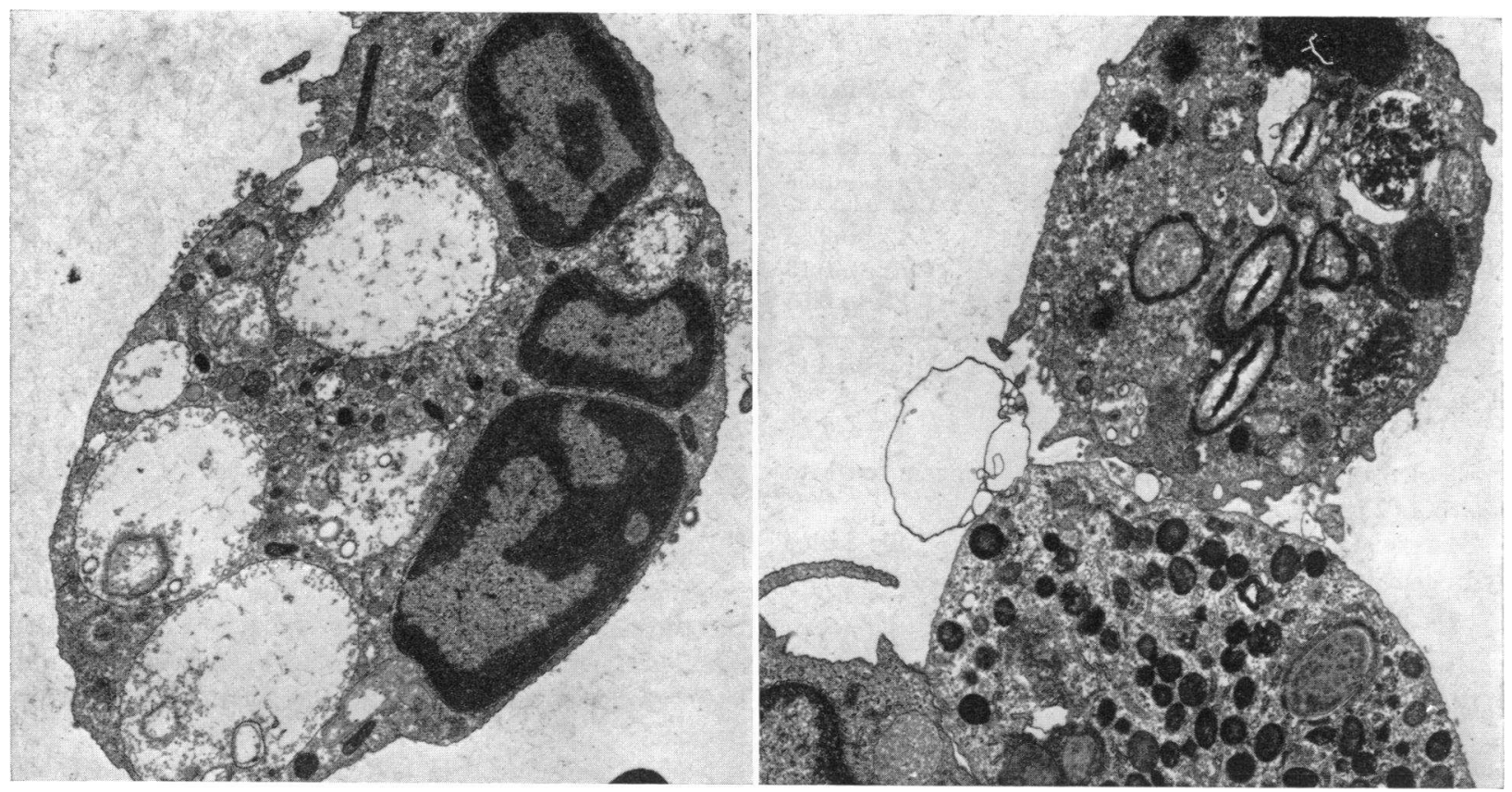

FIGURE 5 Electron micrograph of control (left) and F. E. (right) PMNL 15 min after ingestion of E. coli isolated from F. E.'s septicemia. Phagocytosis and degranulation of myeloperoxidase into the phagocytic vacuoles is normal. However, there is no digestion of E. coli by $\mathrm{F}$. E. leukocytes.

genase activity was probably lower than the measured values.

\section{DISCUSSION}

In contrast to Negroes with glucose-6-phosphate dehydrogenase deficiency, non-Negroes with this enzyme defect have more severely affected erythrocytes $(24,25)$ and decreased enzymatic activity in skin fibroblasts (26), platelets (27), saliva (28), and leukocytes (29). Our findings of a female Caucasian with moderately deficient red cell G6PD levels and a complete deficiency of leukocyte G6PD is unusual and has never previously been reported.

G6PD is coded by the same gene in leukocytes, erythrocytes, and other tissue cells, and there is an excellent correlation of the electrophoretic abnormalities of G6PD in both leukocytes and erythrocytes of affected variants (30). However, as previously noted $(24,25)$ considerable differences in activity of the enzyme may be observed between erythrocytes and leukocytes, and in general the deficiency in activity of G6PD in the white cell is less than in the erythrocyte. Since patient F. E. had severely depressed leukocyte G6PD levels as compared to her erythrocytes, several hypotheses must be considered.

First, the hypothesis that the patient might be homozygous for one of the known $\mathrm{X}$-linked genes resulting in G6PD deficiency can be excluded. Her only son, four brothers, and two sisters have been examined and have normal G6PD levels.

Secondly, the patient might be homozygous for a previously undescribed autosomal gene whose phenotypic expression is selective destruction or inactivation of G6PD in leukocytes. It is well established that the process of cell differentiation involves the permanent suppression of certain enzymes in specific cell lines. Some enzymes that are genetically coded in all cells are produced in measurable quantity only in certain specialized cells. It is possible that the leukocytes of this patient produced an unidentified enzyme that inactivates G6PD as rapidly as it is formed. This hypothesis is compatible with the patient's family history and the current concepts of G6PD genetics, but we have no biochemical evidence to substantiate the existence of the postulated G6PD-destroying enzyme.

Thirdly, more than one gene may affect the level of G6PD activity. Phillips, Herring, Goodman, and King (31) found increased levels of G6PD and alkaline phosphatase in mongoloids. Since the genetic defect results from trisomy 21 , other genes must modify G6PD activity as well as the $\mathrm{X}$-chromosome. It is known that G6PD is an adaptive enzyme (32).

In addition, the patient might be heterozygous for a previously undescribed mutant gene at the G6PD locus of the X-chromosome resulting in formation of a highly unstable variant of G6PD. This may be similar to the 
Philadelphia $(\mathrm{Ph})$ chromosome marker of chronic myelogenous leukemia in which the $\mathrm{Ph}$ chromosome is found in erythrocytic and granulocytic precursors, but not in circulating lymphocytes (33). The postulated variant might be much more unstable in the biochemical environment of the leukocyte than in that of the erythrocyte, and thus be destroyed rapidly and selectively in leukocytes. Even if one assumes a marked difference in stability of the enzyme in leukocytes and erythrocytes, it would still be necessary to assume that the X-chromosome bearing the mutant gene is the active one in most leukocytes.

Fifthly, the patient might be heterozygous for one of the known X-linked genes for G6PD. The finding of moderately reduced G6PD activity in her erythrocytes and the normal level in her son and sibling suggest this. The virtual absence of G6PD activity in her leukocytes could then be an expression of cellular mosaicism with inactivation of the normal $\mathrm{X}$-chromosome in stem cells of the granulocytic cell line in accordance with the Lyon hypothesis $(34,35)$. Inactivation of one of the $\mathrm{X}$-chromosomes may occur quite early in embryonic life $(36,37)$, and by chance the $\mathrm{X}$-chromosome bearing the mutant gene for G6PD deficiency may have remained active in the cell precursor to granulocytes in this patient, while the normal $\mathrm{X}$-chromosome was inactivated. This hypothesis is compatible with the observation in this family. However, if leukocytes and erythrocytes have a common precursor cell (30), another unknown genetic mechanism must be implicated.

It has been shown that white cells contain proteinases which can inactivate G6PD (38). Whether decreased thermostability or the existence of autosomal modifying genes for G6PD could account for this deficiency is unknown.

Thus, patient F. E. must be uniquely different from any previously reported G6PD variant. Additional genetic or environmental factors must exist to explain the marked variability in leukocyte G6PD activity observed in caucasians with this enzymatic deficiency.

Caucasians with glucose-6-phosphate dehydrogenase deficiency have been found to have varying levels of this enzyme in their leukocytes. Rodney, Jacob, Holmes, McArthur, and Good (39) studied a patient with glucose-6-phosphate dehydrogenase deficiency with only $25 \%$ of normal levels in leukocytes. No metabolic or bactericidal defect was found. Ramot et al., (29) found $20 \%$ of normal glucose-6-phosphate dehydrogenase activity in leukocytes. No increased incidence of infections was noted in this population but functional studies were not performed on phagocytes.

Additional studies by Baehner, Johnston, and Nathan (40) in glucose-6-phosphate dehydrogenase-deficient Caucasians showed no metabolic defect when glucose-6- phosphate dehydrogenase was $20 \%$ of normal in phagocytes. However, a patient with only $5 \%$ glucose-6-phosphate dehydrogenase in leukocytes was found to have a reduced pyridine nucleotide pool with moderate functional impairment. Patient F. E. with nonspherocytic hemolytic disease secondary to glucose-6-phosphate dehydrogenase deficiency was found to have a complete absence of this enzyme in her leukocytes.

F. E. phagocytes shared many of the metabolic, morphologic, and bactericidal defects present in CGD cells. Both cells took up bacteria normally and discharged their granule hydrolyases into the phagocytic vacuoles (41). Despite this, both cells failed to evince the oxidative burst that usually begins 1-2 min after particle uptake $(42,43)$. The oxidation of glucose via the HMPS and $\mathrm{H}_{2} \mathrm{O}_{2}$-dependent formate oxidation did not occur. Neither cell killed those bacteria which themselves failed to generate $\mathrm{H}_{2} \mathrm{O}_{2}$, e.g., $S$. aureus and $E$. coli, yet both cells effectively killed peroxide-forming bacteria e.g. S. faecalis. The difference between F. E. and CGD cells was that F. E. cells completely lacked G6PD and had normal oxidase activity, whereas fresh CGD cells had normal levels of G6PD, but were deficient in oxidase activity. Hence, CGD cells demonstrated increased HMPS activity in response to methylene blue, but F. E. cells remained unstimulated because the substrate donor of electrons and $\mathrm{H}^{+}$ions, $\mathrm{NADPH}$, was not produced in G6PD-deficient cells.

The metabolic basis for the bactericidal defect in F. E. cells, as well as CGD cells, would appear to be lack of activity of the $\mathrm{H}_{2} \mathrm{O}_{2}$-myeloperoxidase-halide system (44). Klebanoff (10), and McRipley and Sbarra (45), have demonstrated a synergistic effect between $\mathrm{H}_{2} \mathrm{O}_{2}$, myeloperoxidase, and an oxidizable substrate such as a halide ion. Strauss, Paul, Jacobs, and Sbarra (46) showed that myeloperoxidase-containing granules from guinea pig PMN catalyzed the deamination and decarboxylation of amino acids if $\mathrm{H}_{2} \mathrm{O}_{2}$ were added to the system. They further suggested that the aldehyde formed from the above reaction may be the volatile bactericidal substance proposed by Klebanoff. Myeloperoxidase was normal in F. E. cells and was degranulated into the phagocytic vacuole during phagocytosis. Lehrer and Cline (47) described a patient with disseminated candidiasis and absent PMN granule myeloperoxidase. There was defective killing of Candida albicans and other candida species as well as $S$. marcescens and $S$. aureus. Klebanoff (48) has shown that these cells do not iodinate bacteria since they lack an important component of the $\mathrm{H}_{2} \mathrm{O}_{2}$-myeloperoxidase-halide system, i.e. granule myeloperoxidase. Klebanoff (44) has further shown that CGD cells do not iodinate nonperoxide-forming bacteria within their phagocytic vacuoles. However, they do iodinate peroxideforming bacteria, since the latter bacteria provide the 
$\mathrm{H}_{2} \mathrm{O}$, which is not generated by CGD leukocytes during phagocytosis. The failure of F. E. cells to iodinate bacteria was most likely also due to failure of $\mathrm{H}_{2} \mathrm{O}_{2}$ generation during phagocytosis.

$\mathrm{H}_{2} \mathrm{O}_{2}$ is normally generated in PMN during phagocytosis as first noted by Iyer, Islam, and Quastel (5) who studied the catalatic oxidation of formate $-{ }^{14} \mathrm{C}$ by $\mathrm{H}_{2} \mathrm{O}_{2}$. Several $\mathrm{H}_{2} \mathrm{O}_{2}$-producing cyanide insensitive oxidase enzymes have been described in human PMN : NADPH oxidase $(8), \mathrm{NADH}$ oxidase $(5,6)$ and $\mathrm{D}$ amino acid oxidase (9). Although neither reduced pyridine nucleotide oxidase was deficient in one group of CGD patients (3), NADH oxidase was found to be low in five children with the disease (49). Amino acid oxidase activity was found to be normal in three children with CGD (50). Since F. E. cells had normal NADPH and NADH oxidase activity, this suggested that the substrates for oxidase activity were diminished in F. E. cells, i.e. NADPH and/or NADH. If $\mathrm{H}_{2} \mathrm{O}_{2}$ were produced from both substrates, then neither reduced pyridine nucleotide was available for the oxidase reaction in F. E.'s G6PD-deficient leukocytes. Methylene blue, a potent redox dye, failed to stimulate the HMPS in F. E. cells which indicates that at least NADPH was not available. Evans and Kaplan (51) have described a NADPH-NAD ${ }^{+}$transhydrogenase in human PMN, and such a shuttle mechanism may be important to provide the additional $\mathrm{NADH}$ needed for $\mathrm{H}_{2} \mathrm{O}_{2}$-producing oxidase activity in PMN.

Recently, Schlegal and Bellanti (52) hypothesized a relationship between glucose-6-phosphate dehydrogenase lability and/or deficiency and the increased susceptibility of males to infection. This concept was challenged by Rodney et al. (39), who found no evidence for decreased bactericidal activity of leukocytes from two patients with Caucasian glucose-6-phosphate dehydrogenase deficiency whose white cells contained only $25 \%$ of normal glucose-6-phosphate dehydrogenase levels. This suggests that glucose-6-phosphate dehydrogenase capacity for hexose monophosphate shunt activity is much greater than that which is absolutely necessary for functional integrity of the shunt, and that the enzyme is only rate-limiting if severely depressed.

This observation was supported by the study of a patient with only $5 \%$ of normal leukocyte glucose-6phosphate dehydrogenase activity. Metabolic and bactericidal defects similar to but milder than those of patient (F. E. were found (40).

The patient (F. E.) with a complete deficiency of leukocyte glucose-6-phosphate dehydrogenase showed no evidence of hexose monophosphate shunt activity and, in addition, the hexose monophosphate shunt could not be stimulated with methylene blue. This suggests that activation of the hexose monophosphate shunt is important for adequate bactericidal activity of the polymorphonuclear leukocyte.

However, a recent study in one of our laboratories studying the effect of colchicine on polymorphonuclear metabolism raised a possibility of other mechanisms (53). We found that colchicine, a potent inhibitor of glucose-6-phosphate dehydrogenase, could completely inhibit the respiratory burst, decrease nitroblue tetrazolium reduction by $50 \%$, and partially inhibit iodination. However, there was no effect of colchicine on the ingestion and bactericidal activity of leukocytes. This would suggest that activation of the hexose monophosphate shunt is a secondary mechanism which occurs after the generation of $\mathrm{H}_{2} \mathrm{O}_{2}$ and that intracellular killing may occur in the absence of hexose monophosphate shunt activity.

Thus, the polymorphonuclear leukocyte is endowed with multiple killing mechanisms and most likely has an overkill capacity. However, patient F. E. with normal acid and alkaline phosphatase and beta glucuronidase levels, increased myeloperoxidase activity, and normal degranulation was shown to have a defect in iodination and an inability to kill non- $\mathrm{H}_{2} \mathrm{O}_{2}$-producing bacteria. This suggests that $\mathrm{H}_{2} \mathrm{O}_{2}$ is an extremely important component of the bactericidal system and that alternative killing mechanisms could not adequately compensate for this complete deficiency of glucose-6phosphate dehydrogenase in the polymorphonuclear leukocyte.

Although the precise biochemical basis for $\mathrm{H}_{2} \mathrm{O}_{2}$ production during phagocytosis in human polymorphonuclear leukocytes may still be unsettled, this patient demonstrated that the integrity of the hexose monophosphate shunt is necessary for adequate $\mathrm{H}_{2} \mathrm{O}_{2}$ production and bacterial killing.

\section{ACKNOWLEDGMENTS}

We are indebted to Dr. C. Nash Herndon, Professor and Chairman of the Department of Genetics at the Bowman Gray School of Medicine for expert genetic counsel in this study.

The excellent technical assistance of Miss Hazel Hooper, Mrs. Cindy Shannon, Mrs. Barbara Miller, and Mrs. Sue Cousart is gratefully acknowledged.

This work was supported in part by National Institutes of Health Grant RR-5405, A1 09169, NCI-CAO-8037, 5-RIO-CA-03927, Brown-Hazen Grant from the Research Corporation, Forsyth Cancer Service, American Cancer Society T290D, and the National Medical Foundation.

\section{REFERENCES}

1. Berendes, H., R. A. Bridges, and R. A. Good. 1957. A fatal granulomatosis of childhood: the clinical study of a new syndrome. Minn. Med. 40: 309.

2. Holmes, B., P. G. Quie, D. B. Windhorst, and R. A. Good. 1966. Fatal granulomatous disease of childhood: 
an inborn abnormality of phagocytic function. Lancet. 1: 1225

3. Holmes, B., A. R. Page, and R. A. Good. 1967. Studies of the metabolic activity of leukocytes from patients with a genetic abnormality of phagocytic function. J. Clin. Invest. 46: 1422.

4. Baehner, R. L., and D. G. Nathan. 1967. Leukocyte oxidase defective activity in chronic granulomatous disease. Science (Washington). 155: 835.

5. Iyer, G. Y. N., D. F. M. Islam, and J. H. Quastel. 1961. Biochemical aspects of phagocytosis. Nature (London). $192: 535$.

6. Baehner, R. L., N. Gilman, and M. L. Karnovsky. 1970. Respiration and glucose oxidation in human and guinea pig leukocytes: comparative studies. J. Clin. Invest. 49: 692.

7. Cagan, R. H., and M. L. Karnovsky. 1964. Enzymatic basis of the respiratory stimulation during phagocytosis. Nature (London). 204: 255.

8. Zatti, M., and F. Rossi. 1966. Mechanism of the respiratory stimulation in phagocytizing leukocytes. The $\mathrm{KCN}$ insensitive oxidation of $\mathrm{NADPH}_{2}$. Experientia (Basel). 22: 758.

9. Cline, M. J., and R. I. Lehrer. 1969. D-amino acid oxidase in leukocytes: a possible D-amino acid linked antimicrobial system. Proc. Nat. Acad. Sci. U. S. A. 62: 756.

10. Klebanoff, S. J. 1967. Iodination of bacteria: a bactericidal mechanism. J. Exp. Med. 126: 1063.

11. Baehner, R. L., D. G. Nathan, and M. L. Karnovsky. 1970. Correction of metabolic deficiencies in the leukocytes of patients with chronic granulomatous disease. J. Clin. Invest. 49: 865.

12. Johnston, R. B., Jr., and R. L. Baehner. 1970. Improvement of leukocyte bactericidal activity in chronic granulomatous disease. Blood. 35: 350 .

13. DeChatelet, L. R., and M. R. Cooper. 1970. A modified procedure for the determination of leukocyte alkaline phosphatase. Biochem. Med. 4: 61 .

14. Baehner, R. L., and D. G. Nathan. 1968. Quantitative nitroblue tetrazolium test and chronic granulomatous disease. N. Engl. J. Med. 278: 971.

15. Beck, W. S. 1958. The control of leukocyte glycolysis. J. Biol. Chem. 232: 251.

16. Beck, W. S. 1958. Occurrence and control of the phosphogluconate oxidation pathway in normal and leukemic leukocytes. J. Biol. Chem. 232: 271.

17. Sbarra, A. J., and M. L. Karnovsky. 1959. The biochemical basis of phagocytosis. I. Metabolic change during the ingestion of particles by polymorphonuclear leukocytes. J. Biol. Chem. 234: 1355.

18. DeChatelet, L. R., M. R. Cooper, and C. E. McCall. 1970. Complete absence of leukocyte alkaline phosphatase activity from leukocytes of patients with chronic granulocytic leukemia. Clin. Chem. 16: 798.

19. Gornall, A. G., C. J. Baradawill, and M. M. David. 1949. Determination of serum protein by the biuret reaction J. Biol. Chem. 177: 751.

20. Horecker, B. L., and P. Z. Symrniotis. 1955. 6-Phosphogluconic dehydrogenase. In Methods in Enzymology. S. P. Colowick and N. O. Kaplan, editors. Academic Press Inc., New York. 1: 323.

21. Kornberg, A. P., and L. D. Horecker. 1955. Glucose-6phosphate dehydrogenase. In Methods in Enzymology. S. P. Colowick and N. O. Kaplan, editors. Academic Press Inc., New York. 1: 323.
22. Baehner, R. L., M. J. Karnovsky, and M. L. Karnovsky. 1969. Degranulation of leukocytes in chronic granulomatous disease. J. Clin. Invest. 48: 187.

23. Maaløe, O. 1946. On the relation of Alexin and Opsonin. Munksgaard, Copenhagen. 186.

24. Kirkman, H. N., P. R. McCurdy, and J. L. Naiman. 1964. Functionally abnormal glucose-6-phosphate dehydrogenases. Cold Spring Harbor Symp. Quant. Biol. 29: 391 .

25. Marks, P. A., and R. T. Gross. 1959. Erythrocyte glucose-6-phosphate dehydrogenase deficiency: evidence of difference between Negros and Caucasians with respect to the genetically determined trait. J. Clin. Invest. 38: 2253.

26. Nitowsky, H. M., R. G. Davidson, D. D. Soderman, and B. Childs. 1966. Glucose-6-phosphate dehydrogenase activity of skin fibroblast culture from enzyme-deficient subjects. Johns Hopkins Med. J. 117: 363.

27. Grant, B., A. Szeinberg, A. Adam, C. Sheba, and D. Gafni. 1959. A study of subjects with erythrocyte glucose-6-phosphate dehydrogenase deficiency: investigation of platelet enzymes. J. Clin. Invest. 38: 1659.

28. Ramot, B., C. Shela, A. Adam, and I. Ashkendye. 1960. Erythrocyte glucose-6-phosphate dehydrogenase deficient subjects: enzyme levels in saliva. Nature (London). 185: 931.

29. Ramot, B., S. Fisher, A. Szeinburg, A. Adam, C. Sheba, and D. Gafni. 1959. A study of subject with erythrocyte glucose-6-phosphate dehydrogenase deficiency. II. Investigation of leukocyte enzymes. J. Clin. Invest. 38: 2234.

30. Gandini, E., and S. M. Gartler. 1969. Glucose-6-phosphate dehydrogenase mosaicism for studying the development of blood cell precursors. Nature (London). 224: 599 .

31. Phillips, J., R. M. Herring, H. O. Goodman, and J. S. King. 1967. Leukocyte alkaline phosphatase and erythrocyte glucose-6-phosphate dehydrogenase in Down's syndrome. J. Med. Genet. 4: 268.

32. Johnson, B. C., K. Moser, and H. F. Sassoon. 1966. Dietary induction of liver glucose-6-phosphate dehydrogenase in the rat. Proc. Soc. Exp. Biol. Med. 121: 30.

33. Whang, J., E. Frei, J. H. Tjio, P. P. Carbone, and Brecher, G. 1963. Blood. 22 : 664.

34. Lyon, M. F. 1961. Gene action in the X-chromosome of the mouse. Nature (London). 190: 372.

35. Davidson, R. G., H. M. Nitowsky, and B. Childs. 1963. Demonstration of two populations of cells in the human female heterozygous for G-6-P.D. variants. Proc. Nat. Acad. Sci. U. S. A. 50: 481.

36. Nance, W. E. 1964. Genetic tests with a sex-linked marker: G-6-P. D. Cold Spring Harbor Symp. Quant. Biol. 29: 415.

37. Linder, D., and S. M. Gartler. 1965. Distribution of G-6-P. D. electrophoretic variants in different tissues of heterozygotes. Amer. J. Hum. Genet. 17: 212.

38. Yoshida, A., G. Stamatoyannopoulos, and A. G. Motulsky. 1968. Biochemical genetics of glucose-6-phosphate dehydrogenase variation. Ann. N. Y. Acad. Sci. 155: 868.

39. Rodney, C. E., H. S. Jacob, B. Holmes, J. R. McArthur, and R. A. Good. 1970. Leukocyte glucose-6phosphate dehydrogenase level and bactericidal activity. Lancet. $1: 358$

40. Baehner, R. L., R. B. Johnston, Jr., and D. G. Nathan. 1971. Reduced pyridine nucleotide content in glucose-6- 
phosphate dehydrogenase deficient granulocytes. J. Clin. Invest. 50: $4 \mathrm{a}$. (Abstr.)

41. Cohn, A. Z., and J. G. Hirsch. 1960. The influence of phagocytosis on the intracellular distribution of granule associated components of polymorphonuclear leukocytes. J. Exp. Med. 112: 1015.

42. Karnovsky, M. L. 1962. Metabolic basis of phagocytic activity. Physiol. Rev. 42: 145.

43. Baldridge, C. W., and R. W. Gerand. 1933. The extra respiration of phagocytosis. Amer. J. Physiol. 103: 235.

44. Klebanoff, S. J., and L. R. White. 1969. Iodination defect in the leukocytes of a patient with chronic granulomatous disease of childhood. N. Engl. J. Med. 280: 460.

45. McRinley, R. J., and A. J. Sbarra. 1967. Role of the phagocyte in host-parasitic interactions. XI. Relationship between stimulated oxidative metabolism and hydrogen peroxide formation and intracellular killing. J. Bacteriol. 94: 1417.

46. Strauss, R. R., B. B. Paul, A. A. Jacobs, and A. J. Sbarra. 1970. Role of the phagocytes in host parasite interaction XXII. $\mathrm{H}_{2} \mathrm{O}_{2}$ dependent decarboxylation and deamination by myeloperoxidase and its relationship to antimicrobial activity. J. Reticuloendothel. Soc. 7: 743.
47. Lehrer, R. I., and M. J. Cline. 1969. Leukocyte myeloperoxidase deficiency and disseminated candidiasis: the role of myeloperoxidase in resistance to candida infection. J. Clin. Invest. 48: 1478.

48. Klenbanoff, S. J. 1970. Myeloperoxidase : contribution to the microbial activity of intact leukocytes. Science (Washington). 169: 1095.

49. Baehner, R. L., and M. L. Karnovsky. 1968. Deficiency of reduced nicotinamide adenine dinucleotide oxidase in chronic granulomatous disease. Science (Washington). $162: 1277$.

50. Eckstein, M. R., R. L. Baehner, and D. G. Nathan. 1971. Amino acid oxidase of leukocytes in relation to $\mathrm{H}_{2} \mathrm{O}_{2}$ mediated bacterial killing. J. Clin. Invest. 50: 1985.

51. Evans, A. E., and N. O. Kaplan. 1966. Pyridine nucleotide transhydrogenase in normal and leukemic leukocytes. J. Clin. Invest. 45: 1268.

52. Schlegal, R. J., and J. A. Bellanti. 1969. Increased susceptibility of males to infection. Lancet. 2: 826.

53. DeChatelet, L. R., M. R. Cooper, and C. E. McCall. 1971. Dissociation by colchicine of the hexose monophosphate shunt activation from the bactericidal activity of the leukocyte. Infec. Immunity. 3: 66. 